\title{
Exploring the Malaysian Rural School Teachers' Professional Local Knowledge in Enhancing Students' Thinking Skills
}

\author{
Hazri Jamil ${ }^{1}$, Rohani Arbaa $^{2} \&$ Mohamad Zohir Ahmad ${ }^{1}$ \\ ${ }^{1}$ School of Educational Educational Studies, Universiti Sains Malaysia, Malaysia \\ ${ }^{2}$ Minsitry of Education, Malaysia \\ Correspondence: Hazri Jamil, David School of Educational Educational Studies, Universiti Sains Malaysia, 11800 \\ Penang, Malaysia. E-mail: hazri@usm.my
}

Received: August 24, 2016

doi:10.5539/jel.v6n2p25
Accepted: September 30, 2016 Online Published: December 13, 2016

URL: http://dx.doi.org/10.5539/jel.v6n2p25

\begin{abstract}
This paper discussed a qualitative research findings on the case of Malaysian teachers employed their professional local knowledge for enhancing students' thinking skills in classroom practices. In this paper, a teacher's professional local knowledge is viewed as a teacher's professional knowledge and skills developed through the combination of the teacher's expertise, theory, knowledge and experiences gained from professional practices in various and different contexts of students' social backgrounds, environment and culture. In this case study, we investigate four teachers from various disciplines and schools located in rural areas who are implementing student-centered teaching approach in the classroom. We identified the method, techniques and approaches they employed to enhance students' thinking skills via observations and interviews regarding their teaching practices in the classroom. The study has shown how teachers practice their professional local knowledge through various approaches, strategies and techniques that form positive interaction between teachers and students. This often emboldens intellectual discourse, and gives the students learning autonomy during the process of teaching and learning to improve their thinking skills.
\end{abstract}

Keywords: teacher's professional local knowledge, teachers' knowledge, thinking skill, teaching and learning

\section{Introduction}

Teacher plays a significant role in influencing student learning outcomes and potentially changing attitudes and student status as prescribed in a curriculum (Hattie, 2003; Darling-Hammond, 2000; Sanders \& Rivers, 1996; Slavin, 1996; How, 2007; Salleh, 2003). Studies indicated that there are differing achievements between students who are taught by high quality teachers with students who are taught by low-quality teachers (Hattie, 2003; Darling-Hammond, 2000; Sanders \& Rivers, 1996; Slavin, 1996) and how teachers cope with the distinction of their students socioeconomic background in determining students achievement (Rowe, 2002, 2000; Fredricks \& Rhodes, 2004). Towards the early 80 s, most of the teachers' knowledge was more concentrated on the study of knowledge and the effectiveness of certain approaches and rules which can improve the achievement of students (Richardson, 1994; Veerloop et al., 2001; Johnson, 2006). However, the study of pedagogy cannot be generalised in all circumstances and differing contexts as not all the approaches and models of teaching are appropriate under the differing and unique circumstances and context.

\section{Teacher's Professional Local Knowledge}

Grossman (1990) who explored the professional knowledge of teachers, stated that apart from subject content knowledge, general pedagogical knowledge and pedagogical content knowledge, teachers also need to familiarise themselves with context knowledge in carrying out their professional practice. He defines teacher's professional local knowledge as a teacher's knowledge of the context and background of the school environment, the knowledge of the students and the community, students' background, family, strengths, weaknesses and interests of students. Cochran-Smith and Lytle (1999) describe teachers' local knowledge as to how teachers come to know about their own knowledge through teacher research and also what communities of teacher researchers come to know when they build knowledge collaboratively. It also refers to the process of knowledge construction as they are expressed in and integrated with daily life in schools and classrooms, and the link of knower to what is known and the context in which it is known (Cochran-Smith \& Lytle, 1999). 
Teachers' professional knowledge is not something static, but it is built in an environmental context through experience, reflection and knowledge of the teachers (Liu, 2010) which includes the teachers' knowledge on practical aspects of their pedagogy that is appropriate to the context and background of the students (Connelly, Clandinin, \& He, 1997). Connelly et al. (1997) indicated that practical knowledge and experience of the teacher are in the minds and souls of the teachers now, and in the plans and actions of the teacher in the future. Cochran-Smith and Lytle (1999) have outlined three conceptions of teacher knowledge and learning namely; (i) knowledge for practice, (ii) knowledge in practice, and (iii) knowledge of practice. Knowledge for practice is defined as formal knowledge or general theories and findings of the various topics that are fundamental to knowledge of teaching. It covers the basic knowledge as outlined by Shulman (1987) and Grossman (1990) of content knowledge, general pedagogical knowledge, curriculum knowledge, pedagogical content knowledge and teaching knowledge and school context. This knowledge is the knowledge available and the teacher only needs to apply the received knowledge into practical situations. Knowledge in practice is a practical knowledge, or what very competent teachers know as it is embedded in practice and in teachers' reflections on practice. Knowledge of practice is when teachers make systemic inquiry of teaching, students and learning, subject content and curriculum, the school and the school, and eventually creates knowledge about effective teaching.

Practical knowledge is also a source of knowledge among teachers as described by Shulman (1987) and he expressed that this knowledge is essential to explore. For Connelly et al. (1997), personal practical knowledge is significant as it is the result of their personal experience rather than learned and transferred. This include teachers' knowledge of the context, students' background and their influences in every aspect of their teaching practice, the relationship between teacher and student, teachers' interpretation of the content of the subject and its importance in the lives of students, teachers' interpretation of the idea of processing and assessment of student progress (Connelly et al., 1997). This knowledge is also the result of the teachers' reflection (Schon, 1987) and serves as a corrective measure that allows meta-learning on effective teaching practices (Guzman, 2009). Schon (1987) stressed the need for professional practitioners to adopt reflection in action and reflection on action to build their knowledge. Canagarajah (2002) asserted that it is the efforts of teachers to develop effective strategies of teaching and learning generated from the students and schools environment in their daily context, which may not conform to the recommendations of the ministry which can also be regarded as a tacit knowledge, or craft, which are often not disclosed and acquired and developed from teacher's experiences and their professional practices. Gholami (2009) summed up this knowledge as what MacIntyre (1982) stated "moral and intellectual virtue rooted in a human being's capacity to do the right thing in the right place at the right time in the right way".

\section{Problem Statement}

Thinking skills are recognized as an important and indispensable element for the 21 st century education and are often identified as an objective to be achieved in teaching (Munzenmaier, 2013; Cloke et al., 2006; Onosko \& Newmann, 1994; Halpern, 1996). In Malaysia, the Higher Order Thinking Skills (HOTS) is a key element of the learning outcomes that are given emphasis in the school curriculum. These skills are also a focus on the agenda of Educational Transformation of Malaysia through the Malaysian Education Development Plan 2013-2025 (Ministry of Education, 2013), which aims to produce students who are competitive in a rapidly changing world and in accordance with the educational needs of the 21st century (Ministry of Education, 2013). The implementation of this skill is far more critical in the rural areas. According to the preliminary report of the Malaysia Education Blueprint 2013-2025, the result for the primary school public examinations indicates the gap between urban and rural students is almost 4 percentage points in favour of urban schools. At the secondary school public examinations level, the gap appears to have widened to 8 percentage points (Ministry of Education, 2012).

Studies related to the implementation of HOTS are more focused in determining the effectiveness of techniques in terms of advocating HOTS among students in schools (Rajendran, 2001) regardless of the pedagogical practices practiced by teachers based on their local knowledge in the context of various schools, backgrounds and abilities of students. Hence, educational research on pedagogy and learning outcomes of students should take into account the local knowledge of the teacher who determines the success of the curriculum (Goldenberg \& Gallimore, 1991). Veerloop, Driel and Meijer (2001) proposed a similar view by stating that the goal of the curriculum is more likely to fail if more emphasis was given to build specific skills and knowledge without considering the thinking and knowledge of teachers' based on their beliefs, intentions and desires, and attitudes.

Scholars acknowledge that in an effort to find efficiency in educational practice, the key element that should be considered is the teachers who implement these practices in the context and environment in which they are in (Johnson, 2006; Verloop et al., 2001; Richardson, 1994). Studies conducted in Malaysia showed the teachers' have the ability to adapt their knowledge and skills with the environment and background where they work to improve 
student learning outcomes (Chen, 2005; Mohamad Said, \& Yunos, 2008; Hashim \& Hussein, 2003). Combination of knowledge and experience of teachers in their pedagogical practice in the context of a more in situ should be reviewed, presented and disseminated to provide valuable information about the pedagogical knowledge in the classroom.

\section{Research Question}

The key research question was: How do the Malaysian teachers use their professional local knowledge in their classroom practices for enhancing their students' thinking skills?

\section{Methodology of the Study}

The participants in this research include teachers who apply student-centered teaching practice, selected notably by the school stakeholder as the excellent teachers retrieved from the District Education Office. Schools involved in this study were normal day schools in a rural area with students from the medium academic performance in the northern part of peninsular Malaysia. Students of these schools are achieving modestly and teachers in these schools are posted there by the State Education Department based on the needs of the schools, hence it is not based on any specific criteria. Basic facilities for teaching and learning ICT were also fully available in these schools and learning climate depends on the ability of teachers in a certain teaching and learning (T\&L) process.

\subsection{Research Approach}

This research adopted a qualitative case study approach involving four teachers in three secondary schools situated in rural areas in northern peninsular Malaysia. This study supports the views of Miles and Huberman (1994) in a purposive sampling that is guided by a social theory that already exists that is the guided sampling theory (theory -based sampling ) or selective sampling ( Neergaard \& Olho, 2006; Patton, 2002). This leads the researcher customarily chosen the best individual or field that can help researchers fully understand the phenomenon being studied (Miles \& Huberman, 1994; Marshall \& Rossman, 2006; Creswell, 2012). Hence, the selected teachers in this study are those that met the criteria of teachers who were implementing student-centred teaching approach based on the checklist of teacher's classroom environment and verified by the schools' stakeholders and senior colleagues. Four participants in this study were given pseudonyms. They are: Ms. Azim, Ms. Emi, Ms. Hani and Ms. Leha. Table 1 below shows their profile.

Table 1. Research participant profile

\begin{tabular}{cllccccc}
\hline Participant & $\begin{array}{l}\text { Name } \\
\text { (Pseudoname) }\end{array}$ & Gender & Age & Race & $\begin{array}{l}\text { Teaching } \\
\text { experience (Year) }\end{array}$ & Teaching subject & Level \\
\hline 1 & Azim & Female & 38 & Malay & 15 & English & Form 4 \\
2 & Emi & Female & 36 & Malay & 12 & Islamic Education & Form $1 \& 4$ \\
3 & Hani & Female & 44 & Malay & 20 & History & Form 4 \\
4 & Leha & Female & 35 & Malay & 11 & Commerce & Form 5 \\
\hline
\end{tabular}

Methods of data collection for this research were through a series of observations and semi-structured interviews. A total of five observations on teaching and learning (T\&L) in the classroom were done for each of the study participants (teachers). Thematic analysis was conducted on data obtained deductively and inductively to identify important themes on the professional local knowledge of teachers in their T\&L practice in the classroom to enhance students' thinking skills.

\subsection{Trustworthiness of the Study}

Validity and reliability are essential in determining the quality of a study. According to Morse, Barrett, Mayan, Olson and Spiers (2002), without validity and reliability (or termed as "rigor"), the review would be meaningless, is fiction and will lose its usefulness. In the context of this qualitative research, both aspects are represented by the concept of trustworthiness. Several strategies have been used in this study to ascertain the validity or credibility of the study which include the triangulation of the data, member check, debriefing and auditing. In this study, the dependability and credibility of the research were assessed in two steps. During the thematic analysis, two 
researchers independently coded the interview transcripts. The detailed coding was discussed through an iterative process until the final themes emerged. The same process was used for the observation data.

Triangulation of various sources (Lincoln \& Guba, 1985; Miles \& Huberman, 1994; Golafshani, 2003; Shenton, 2004; Yin, 2009; Creswell, 2012) was used in this study to ensure the credibility of the study and has enhanced the trustworthiness of the data analysis. For example, through the interview with Ms. Emi, she was emphasizing the use of visual display such as images, video, maps or mind maps in stimulating students to directly engage in activities that can improve their thinking skills. This was also proven in the observation of her classroom practices when she made a video presentation and used pictures to encourage the weaker students in the process of thinking. In addition, during the analysis of her students' books, a mind map notes developed by the students can be seen in accordance to what she had emphasized in the interview. Furthermore, member checking method, where researchers acquire confirmation or correction of data (Lincoln \& Guba, 1985; Shenton, 2004; Yin, 2009; Creswell, 2012) of the study participants was also conducted to enhance the credibility of the study which involved study participants, numbers of professional colleagues to attend the debriefing session presentation of the findings, especially during the formation of the theme by researchers and discussions with other professional colleagues who were not involved in the study allowed researchers to reassess the interpretation that was made and avoid bias or tendency (Lincoln \& Guba, 1985; Shenton, 2004; Burnard et al., 2008).

\subsection{Addressing the Ethical Issue Related to the Study}

A number of potential ethical issues were considered. These included how best to negotiate access to the schools and participants as well as the possible disruption to individual participants and particularly teachers and students. Therefore, the researchers and teachers worked together to organize the interview and observation schedules so that the timetable was not disrupted. The consequences of the research towards the participants were also considered as an important area of concern especially concerning any official reports or future publications. Hence, the names of the schools and the participants remained anonymous and all data were confidential to the researchers. All participants were given verbal and written information about the research prior to the data collection. Signed consent forms were collected for the interview and observation sessions. All participants were advised of their right to withdraw or refuse to participate in the research at any stage.

\section{Research Findings}

The findings show that a variety of approaches and methods developed by study participants through their professional local knowledge in T\&L environment in the classroom and students were able to increase the diversity of students' thinking skills. Teachers' consideration of the context, background and differences in the ability of students showed how teachers adapt their professional practices to ensure they are doing the effective and appropriate way to achieve the desired learning outcomes.

Based on the thematic data analyses from the study of four cases of teachers' classroom practices, four themes have been generated in regard to how the teachers use their professional local knowledge to enhance students' thinking skills. The themes included probing student's thinking by questioning, debating, learning autonomy and discussing controversial current issues.

\subsection{Probing Students' Thinking by Questioning}

Stimulus to students in performing activities of thinking was done in the classroom with the questions, whether between teachers and students or between students. Question filed by the teacher is then followed by "probing" where the follow-up questions aimed at discovering more about the student's description of the facts, ideas and information submitted. For Ms. Azim, this questioning method was suitable for enhancing thinking skills among her students. Probing was effectively conducted by teachers, especially Ms. Azim to encourage students to express their views. Ms. Azim understood her students' ability and the need to encourage the students to express their views or give explanations, through stimulation with follow-up questions, "Ask repeatedly. Whatever they say, question them back, we're actually making them describe whatever they're saying, they say very little, need to be elaborated" (Ms. Azim/English teacher).

Continuous stimulus to boost students' thinking skills in learning activities through unceasing questions by teachers can be observed in Ms. Azim's class. She often tested the students' understanding by probing them with questions. Critelli and Tritapoe (2010) stated probing is an effective technique to develop the minds of students and promote sustainable responses from them. The answers given by the students will be rewarded with another question to encourage students to continue to think and hence gaining a thorough understanding of the topics discussed. Probing technique (scoop) by Ms. Azim encouraged students to think and ultimately enabled them to 
grasp the concept and content of education. For example, it can be seen in both teaching observations of Ms. Azim when the students presented the poem "He Had Such Quiet Eyes".

Student: One day a girl met a man who had such quiet eyes, but she didn't realize that the man is such a liar. The eyes belong to a liar, the girl started falling in love with the man without knowing him very deep inside, lastly from this poem we know that all girls have to read this poem to avoid themselves from this kind of man.

Teacher: Why must we read that poem?

Student: We want to know that ... [unclear response]

Teacher: How do you know that the man is a liar?

Student: By his quiet eyes.

Teacher: But usually when you meet a man, he will give you those eyes, those daring eyes, and how are you going to realize that those eyes are quiet eyes, all eyes I think are quiet eyes.

Student: The way they look.

(Ms. Azim's English class)

Questioning technique is suitable to push students to think and respond to the issues raised by the teacher. Open questions can encourage students to reason and use their existing knowledge (Tofade et al., 2013; Critelli \& Tritapoe, 2010). Teachers in this survey believed that these techniques were suitable in the context of subject content and the ability of their students to use thinking skills. The questions posed were able to get responses from the students. Ms. Emi in her Islamic Education class for example, questions the students in order to guide them to the desired level of thinking. Ms. Emi did not continue to provide an explanation or answer to students in discussions, but trained the students to understand the concept and content of the lessons learned through students' ability to create a relationship.

Teacher: Let's try to look at this verse. What is the relationship between "Satan" and "halal"? Try to make a sentence. Based on the word "halal", based on the word "Satan", because I know you're good at it now. When you see a sentence, Allah says there are "halal" things, Allah says there is "Satan". What is the relationship between Satan and halal? Ok Satan is made of what?

Student: Fire.

Teacher: Ha fire, fire, nature of Satan, what is its nature?

Student: Bad.

Teacher: Bad, arrogant, imperious... Ok, now try to think for a moment, try to make a sentence through the words Satan and halal. Ok Fikri, try to see whether yours is the same as Azman. Write it here.

Student: [student writes on the board "God ordered Muslims to take only 'halal' food and drink and not to listen to Satan"].

Teacher: Ok, good Fikri, now you can relate Satan and halal, Fikri.

(Ms. Emi's Islamic Education class)

Ms. Emi was seen encouraging students to associate two contradictory words, "halal" and "Satan" and came up with suggestions to conclude the association between those words. She helped the students to think by asking questions such as the nature of Satan and directly gave time for the students to think how they could link those two words. The activities carried out in Form 1 classes was seen as a successful attempt to stimulate their minds by trying to make the relationship between the two opposite words and to conclude from the suggestions given. Ms. Emi also encouraged the students to ask questions. According to her, "We have to give the students time to open up their minds to ask. That is important. I guess so" (Ms. Emi/Islamic Education Teacher).

For the teachers, their experience and practical knowledge about the students and suitability of the lesson contents gave them an understanding on the importance of questioning the students to encourage them to think. According to Ms. Hani, questions will help students view the lesson content in a more concrete way, "I do it this way, I give them questions. For this title I give a question, and then we look for content. Or previously I discussed the title of the country's symbols so the students discussed the country's symbols after that I hand them questions. Students can understand it" (Ms. Hani/History Teacher). Based on Ms. Hani's teaching observations, she asked higher order questions to her students in order for them to give explanations. For example, in the first observation while discussing the steps necessary to maintain national unity in Malaysia, the second group provided recommendations 
for the national unity campaign. Ms. Hani then posed questions to stimulate students to develop ideas and elaborate strategic measures for the realization of the proposed campaign.

Teacher: Ok, "national unity" campaign. Can you describe the campaign?

Student: By having neighborhood groups.

Teacher: Try to get up first.

Student: Aspects of society, particularly neighborhood groups hold national unity campaigns such as organizing carnivals, communal cleaning of homes or halls and holding gatherings for feasts.

(Ms. Hani's History class)

Ms. Hani was seen to repeat the question based on the response given by the students who felt somewhat vague about the question, in order to make room for all the students to think and make conclusions based on the facts put forward and eventually be able to bring these discussions to a more precise answer. This can be observed in the third observation of Ms. Hani's teachings.

Student: Ensure efficient administration.

Teacher: Ok well, Faiz said the importance of the national symbol was to ensure efficient administration, how are you going to associate the national symbol to ensure efficient administration?

Student: Moon and stars symbols.

Teacher: Moon and stars symbols?

Student: They symbolize Islam, Muslims have to work efficiently because of the trust given to us.

Teacher: What he means here is that Izzat is associating efficient administration with the moon and the star that symbolize Islam as the official religion. So when Islam is the official religion, the Muslim community will carry out the duty or trust with responsibility. Ok, so what does this meaning here relate to?

Student: Integrity.

Teacher: Integrity, ok apart from that, what else on the coat of arms of our country can be used to associate efficient administration? Tiger?

Student: The motto, unity is strength.

Teacher: Motto, a good idea, this is why I say Afifi has got brilliant ideas if he studies seriously.

(Ms. Hani’s History class)

Similarly, Ms. Leha (Commerce subject teacher) also repeated the questions to improve her students' thinking skills, "I repeated the questions, I asked again, then they will provide opinions" (Ms. Leha/Commerce subject teacher). As can be observed in the third observation, Ms. Leha posed questions to make sure the students understood the fundamentals of the discussion to determine the correct answer for the original question asked. She received responses from students through the questions and focused on specific responses according to the level and ability of her students.

Teacher: Ok the payment was settled within 14 days. How long did he take, how are we going to know within the 14 days?

Student: [student responses were mixed]

Student: Look at 20th April to 2nd May

Teacher: 20th April, 20th April, was it there? In the invoice, the invoice date was on 20th April, how long did it take? When did he pay?

Student: May 2.

Teacher: May 2, so how many days did he take?

Student: 14.

Teacher: Is 14 days enough? Ha, how many days? Start with

Student: Two weeks, teacher

Teacher: Yes, but I want to know how many days. How many days are there in April? 
Student: Two and a half weeks.

Teacher: How many days? April is until 30 or 31 ? How many days?

Student: 12 days, maybe

Student: 13 days.

Teacher: You must start on 20th April, 20 till the end of April and he paid on May 2, right, so he took 13 days.

(Ms. Leha's Commerce subject class)

In addition to probing technique, teachers were also observed to encourage their students to think by giving provocative response to the students which would result the students thinking deeper and continuously. Observations in Ms. Azim English class that discussed issues of dignity of a girl was appropriate with the context and background of her students (all girls) showed an example of provocation technique used to encourage students to think about all the possibilities that can degrade them as a girl.

Student: Before we befriend them we try to investigate their attitude.

Teacher: How do you investigate the attitude? This is not practical, good ladies, how? Ooh ... you do not know how.

Student: [unclear response from the students].

Teacher: What, what is that? Anybody knows? By their movement? Look at what is ok, what kind of behavior ... what kind of behavior?

Student: Like their talking, sweet words.

Teacher: Like their talking, their sweet expressions, [mimicking the words of the student] no I do not think so you know how. People, they are so ... they are very good in pretending you know, guys, they are given a lot of brains actually. How, yeah, ok what is that, tell that in English Nabila.

Student: Boys starting to touch.

Teacher: When they start to what?

Student: Start to hold hand.

(Ms. Azim’s English class)

T\&L activities in the classroom observed of the research participants were also filled with questions among the students. Questions asked by the students are able to bring the students to deeper learning (Tofade et al., 2013). Also, questions by a student to another fellow student will enable both of them to think for a solution for a particular problem. In Ms. Leha's class for example;

Student: Nik, It is like this, the question mentioned about the yellow jaguh rackest, the price of yellow colour jaguh racket per unit is RM 195 multiplied by 50 units, equals to RM9750.

Student: Look at the question, look at the question again, question 3, according to the choices of the quotation, it is mentioned that the mini market decided to purchase 50 units of yellow jaguh rackets, he has chosen 50 yellow jaguh rackets.

Teacher: Understood, Nik? The question required, yellow jaguh rackets only, he doesn't want to purchase all, he only wants to purchase yellow jaguh rackets, and 50 units, so that's why 50 is multiplied by

Student: 195

(Ms. Leha's Commerce subject class)

The discussion began when a student (Nik) asked a question related to the calculation previously presented by their peers. Students who presented the calculations re-explained with regard to the key issue of the question.

Ms. Azim also encouraged her students to ask questions to their friends. The opportunities deliberately provided by Ms. Azim for her students to question the information or facts that were presented by their peers were seen to be able to stimulate students to think and make suggestions and correct errors. This can be seen in the fifth observation where the students asked a few questions to understand the concept of "present tense" and "present continuous tense". This can be seen in the excerpt below:

Student: This [showing the sentence on the board]. My father is watching television. 
Student: No "ing", no "ing"?

Student: The sentence is correct with "ing", if you do not have the word "ing"? My father is watch television. Is that true?

Student: My father is watch television?

Student: Then what must we use?

Student: Say that you can use sing song, can use that also.

Student: You watch television. If you do not put "ing" there is no need for the word "is". Do you understand? He watches television.

Student: The sentence is in the present tense. My father is watching television.

(Ms. Azim's English class)

Confusion occurs when students were requested to present the concept of "present tense" but they presented the "present continuous tense" concept instead. Questions from fellow students led all students to think about concepts that were discussed. The students' ability to identify the main problem and seek a solution as one of its thinking skills that was applied on the students and it was boosted by the questions either from the teachers or the students.

\subsection{Debates-Criticizing and Arguing}

Encouragement and guidance for students to make criticisms and argue are part of the teachers' professional local knowledge to improve their students' thinking skills. To enable students to criticize and argue, the students need to think. Teachers in this study believed their students needed to be encouraged and given opportunities to engage in criticism and arguement for knowledge building and understanding of the topic. Ms. Azim for example, is seen to be encouraging her students to always give criticisms and comments on the information given to them, as she pointed out to her students in the second observation.

Teacher: The rest of you, people who are sitting, you have to ask them questions, don't just agree with them, If you want to criticize, if you want to comment, please do so. Ok don't just accept the fact that is presented by the group. Sometimes they are wrong sometimes you are right or sometimes you might get confused with what they have said, please ask questions, ok, don't just sit still.

(Ms. Azim's English class)

Encouraging students to give opinions and to make criticisms have given the students opportunity to open up their minds and think of other options to resolve the issues under discussion. In the fifth observation of Ms. Azim's lesson, a group of students presented the wrong concept. One of her students was able to identify the fault content of her friends and criticized it. Although the student was seen to be afraid to forward her opinion, the teacher kept on encouraging the student to criticise in a suitable way based on the student's ability.

Student: Teacher, dia bukan buat (Malay words) present tense dia buat (Malay words)...

Teacher: Ok stand stand stand, tak reti cakap English, cakap jelah, cuba cuba, (Malay language) try and speak in English, try, come on.

Student: Dia dia... (Malay word)

Teacher: No no no, in English please, please try, try.

Student: Teacher asks them to give a sentence in the present tense but their sentence is in the present continuous tense.

Teacher: How do you know it is present continuous tense?

Student: Because it has "is" and "ing", present tense you must have "s" or no "s".

(Ms. Azim's English class)

Learning environment involving students making criticisms and arguments can be seen in the Islamic Education class of Ms. Emi through the debate activities. Through issues discussed, namely "polygamy", it gave the students the opportunity to $g$ their views, give arguments and criticise while assessing the concept of justice in the practice of polygamy.

Student: The first wife has ten children; the second wife has five children. Husamudin can't give money equally to both wives as it's not fair. This is the reason I said that to be fair does not mean giving the same amount. 
Student: If it is not the same, if the first wife gets a thousand ringgit, what will the second wife get?

Student: For example, the first wife has 10 children, each will receive RM100 for allowances, if she has ten, and how much would you think her husband would have to give? So if each child receives a total of RM100, her husband must have a lump sum of RM2-3,000.00 for his children and to cover up for food and clothing essentials. His second wife is not eligible to receive that amount of money if she only has 5 children.

(Ms. Emi's Islamic Education class)

The fairness concept by the proposer explained by the student received criticism from the opposing team because their understanding of the concept of justice touches on the definition of equality. After the fourth observation was carried out, Ms. Emi informed that she is yet to teach the topic to her students and this debate was the first activity for the topic of polygamy. She deliberately did so because she wanted the students to first explore the topic and see how they argued, put forward their ideas and understood the concept. Debate activity in the T\&L context can also develop students' attitude and sensitivity to moral issues that affect them through discussion and contextual issues relevant to students' experience and general knowledge. It is the responsibility of educators to teach students to not only think critically but also ethically, morally and be sensitive and not only think for their own individual benefits but also for society. Debate is used as a means to improve thinking skills in Ms. Emi's classroom. Her lesson is in line with the Activity Theory developed by Vygotsky, Leontiev and Ergestrom (cited in Hardman, 2008) which states that debates as activities lead to student learning or as those expressed by Hardman (2008) as "lasting changes" in students' thinking (p. 65). This is also supported by Bloom's Taxonomy of Learning as a learning approach that involves both low as well as high levels of cognitive skills (knowledge, comprehension, application, analysis, synthesis and evaluation). In Ms. Leha's Commerce subject lesson, it can also be observed that the teacher provided space for the students to criticize and argue amongst them.

Student: Ok are there any questions?

Student: In the second example, she wrote that she wanted profits in a short time, right? How can she get it in a short time?

Student: He purchased an asset, right? He bought a house, right... [other students laugh]

Student: Look, how can we get profit in a short period of time?

Student: Short period of time, our house no tax is paid on the house, am I right?

Student: There is assessment.

Student: Recapitulation: what she refers to is the current return, buy a house and rent it out for monthly rental, it is monthly revenue, right? Get monthly rent, get monthly rent.

(Ms. Leha's Commerce subject classes)

Criticism given by their fellow students towards the presenters' examples had opened up their mind, not only to the involved students but to all students who assessed the truth of the information. The ability of students to criticize portrays the thinking process in their minds towards the issues discussed and when the criticism is forwarded it will stimulate the thinking process on the other students.

For Ms. Hani, although the opportunity for students to criticize and argue was not always observed throughout the observation period, in her interview, she asserted the activity carried out was similar to the hot seat and debate method. However, according to her, such activities did not get full cooperation from her students and had to be converted into ordinary discussion activities.

I've tried the hot seat technique, one of the techniques that we can carry out in Literature. The hot seat technique was only successful on two students from the Science class, Shamsul and Najib. These two students read the book thoroughly, made preparations and the other student were able to question them during this task. So, this technique is actually interesting as it can promote competition among students.

(Ms. Hani/History Teacher)

\subsection{Autonomous Learning}

To encourage thinking and problem-solving skills, participants of this study were seen to have made their students responsible towards their learning by giving more autonomy to the students in ensuring a smooth progress of the teaching and learning process. Ms. Azim in the fourth observation for example, empowered her students to determine the question and decide whether the answers given by their fellow students were worth to be given 
marks or otherwise. Ms. Azim used Walt Disney animation video clips as stimuli for students to discuss and prepare questions (along with the correct answers) to be directed to other groups. The opportunity given to the students to answer the questions opened their minds to think and provide a wide range of responses that eventually led to the correct choice of answer. The autonomy granted by Ms. Azim was also seen to have encouraged students to discuss and reach agreement among the members of the group to determine who had the most appropriate response as in the following passage.

Teacher: D (group) is that the answer that you want? Nabihah, Nabila, D (group)..., is that the answer? Ok what is your answer? D (group), is that the answer that you wanted from Subashini? No, ok let $\mathrm{C}$ (group) try, let $\mathrm{C}$ (group) try.

Student: Because his father hated Tarzan before. When Tarzan was young, his mother took care of him

Teacher: Akila, Nabila, Nabiha, [members of D group discuss]

Teacher: Ok D group please stand, there's a crisis here, every member from D group please stand. Ok so which group won, which group got the right answer?

Student: E (group).

Teacher: E (group)? The one which presented the first one? Then you rejected, and then went to the second one and the third one.[other students show dissatisfaction]

Teacher: Alright Nabihah, why did you finally decide that E group was right? What is the reason?

Student: Because he couldn't save the gorilla.

Teacher: Ok, Syifa' please explain in English.

Student: The Tarzan was sad because he couldn't save the gorilla.

Teacher: Ok because Tarzan could not save gorilla's life. That is the answer that you wanted, that's why they decided that $\mathrm{E}$ got the closest answer.

(Ms. Azim's English classes)

Ms. Azim appeared to highly respect the decision made by the students as she did not interfere in the decisions they made. The autonomy she entrusted to her students trained them to think, discuss and reach an agreement to resolve the problems they were facing. This clearly shows that when teachers are willing to give some autonomy to their students, it helps them to sharpen their thinking and problem solving skills.

Another study participant, Ms. Emi gave autonomy to her students through sketch presentation either in the form of advertising or short drama to illustrate the rights of brotherhood in the society. Students were free to decide the rights to be highlighted and how they were going to present it. Ms. Emi put it in this way, "Take me as an example, I will allow the Form 1 students to either create an advertisement or a play on the topic that I gave. I don't want to teach based on the textbook but allow the students to apply it in the play" (Ms. Emi/Islamic Education Teacher). Autonomy given by Ms. Emi has highlighted the creativity of the students. Students added in poems or nasyid, or prepared simple props to enliven their performances.

Ms. Leha on the other hand gave responsibility to her students in conducting quizzes. Students had to prepare questions, find the answers and decide who should answer the question. According to her;

For the quiz on the other day, the students prepared the questions and had to think about it, they even asked me whether the questions they constructed were good. However, there were direct question and also calculations.

(Ms. Leha's Commerce subject classes)

The learning autonomy given to the students to decide the questions together with the answers made the students feel responsible for the success of their teams as they had to choose quality questions and prepared to try to answer the questions given by the other groups. The process of forming and choosing the question helps to stimulate the students to assess the type of questions to be submitted. On the other hand, when they received a question, the group members would work hard to solve it out. The excerpt for the fifth observation shows how the activity encourages the students to think.

Teacher: Ok, please repeat the question. Mr. Fuad invested in ASB for 30,000 units worth one ringgit per unit. Then, PNB declared a dividend of $7.5 \%$. Ok, calculate his revenue. Bonus, ok calculate the dividends and bonuses. 
Student: Calculate the dividend and bonus acquired by Mr. Fuad.

Student: Altogether?

Student: No, stated here dividends and bonuses, dividends and bonuses.

Student: Separately?

Student: Yes, separately.

Teacher: Two different answers, one dividend and one bonus, bonus in the form units. Group 6 ?

Student: His dividend is 4000 units.

Student: Hey dividend.

Teacher: Dividend is in RM, not units.

Student: Bonus 12,000 units.

Student: [student shook his head] Ok [student points at another group].

Student: For dividends, $7.5 \%$ multiply by 30,000 to get 2,250 , for bonus 2.5 multiply by 30,000 to 750 units, correct?

Student: Correct.

(Ms. Leha's Commerce subject classes)

Questions submitted by group 4 in the form of calculation stimulated all the students to think although it was intended to group 6. However, all the groups tried to answer. When it was answered incorrectly, the other groups tried to answer it correctly. The autonomy given to the students also showed the responsibility character (in the group 4 situation) as they were prepared with the correct answer and able to determine which group had answered it correctly.

All three of these teachers (Ms. Azim, Ms. Emi and Ms. Leha) shared some authority with the students to encourage and provide freedom for students to think and make decisions in their learning activities. The teachers gave general guidelines that formed the activities either quizzes, group presentations or even a sketch, while the students decided how the activity would be carried out.

Meanwhile, Ms. Hani was observed to still exert control over her teaching and learning activities. For example, as observed in the second observation. Although Ms. Hani appointed two of her students to conduct the spelling bee quiz, as the chairperson and to record marks, the words to be spelled out were prepared by Ms. Hani. Not many thinking activities could be carried out during this time except at the end of the quiz where the students were required to construct a sentence from high level vocabulary that they have already spelled out ( 5 other sentences as their homework as T\&L was carried for a single period only). The T\&L activity could have been more interesting if Ms. Hani gave the authority to the students to find the vocabulary for their peers to spell out and followed by a sentence as what was done by Ms. Azim and Ms. Leha.

\subsection{Discussing Controversial Current Issues}

The teachers in this study believed that by giving the opportunity to the students to discuss the controversial current issues that are relevant to their lesson content could help to encourage thinking skills among their students. Deuchar (2009) and MacMath (2008) suggest more discussions on current and controversial issues should be carried out in the classroom to encourage students to express their views and opinions.

Discussion of current issues that are related to the lesson taught was observed in the teaching of Ms. Hani. She discussed with her students the insult to the national flag which was the current issue happening in terms of the political and current social contexts. This was brought to the classroom for discussion with the students and it generated various responses from students. Ms. Hani controlled the situation by encouraging students to think of rational views and propose better solutions.

Student: What is the appropriate punishment imposed for insulting the national flag?

Teacher: On whom, people insulting the flag?

Student: We need to catch this kind of people and kill them. [Students laugh]

Teacher: Our country has laws, we recently learned the legal processes. This is what we want to avoid, a small quarrel and what law he suggests? The law of the jungle! He creates his own law. We have laws in this country, we have to follow procedures. If this is what you want to do, if you don't do 
your homework, can I impose public caning? I can't, right. We have laws. Ok, for the person insulting the national flag, what can we do? Another student, what is your opinion, Hairani? No opinion? What will you do Husamudin?

Student: Drag them to justice.

Teacher: Dragging them to justice. Dragging here does not mean we hold his hand and drag him to the police station, but to bring him to justice.

(Ms. Hani's History classes)

During the discussion of controversial issues in the classroom Ms. Emi also initiated a debate among students about polygamy. Polygamy is the title stated in the syllabus of Islamic education in Form 4 and it provides an opportunity for Ms. Emi to encourage debate among her students to make it more controversial and encourage students to think more critically.

The issue of having children in a polygamous marriage used as the popular reason to allow polygamy was discussed critically by the students which also may represent the male point of view. This debate allowed the students to list the positive and negative aspects of polygamy, while understanding the boon in legalizing polygamy. Such debates on current issues provide the student with better knowledge on certain issue besides educating them to respect another person's opinion and improve their debating skills (Deuchar, 2009). These debates can improve critical thinking and communication skills of students with the skills to organize ideas, listening and increase students confidence (Hall, 2011), and as a pedagogical tool that can improve critical thinking skills and learning skills as compared to traditional teaching methods (Yang \& Rusli, 2012).

Based on the observation of the English class by Ms. Azim, the divorce issue was brought up for discussion in class to encourage her students to discuss and think.

Teacher: What about those people who say divorce destroys children's future? Give your reasons. Why the future of the children will be distracted, will be destroyed. Yes, Ainul, what do you want to say?

Student: Because they lack of love from their parents...

Teacher: When they...

Student: Grow up.

Teacher: Ok, during the period of growing up they do not receive love from both of the parents because both parents are not living together anymore, separated and then they don't get enough love from both sides, ok Ainul she has a point, yes Mona.

Student: When parents divorce, they don't care about their children because they fight with each other.

(Ms. Azim's English classes)

This discussion received good responses from students, including students who have had their own experience. The students listed the adverse effects of divorce and how a child could be adversely affected by their parents' divorce.

Another research participant, Ms. Leha did not raise any discussions pertaining to current issues. This may have been because during the observation period, Ms. Leha was more focused on topics that frequently came out during examinations. However, in her interview, Ms. Leha did mention examples of her discussion that were carried such as comparison between conventional insurance concept and Islamic system which created interesting discussion to encourage thinking skills among her students.

(Debating is carried out) according to the circumstances and also the topic. For example, during discussions on the topic of "insurance" we have to relate it to conventional insurance and Takaful (Islamic insurance), if it's Takaful, what will occur? We had an interesting discussion.

(Ms. Leha /Commerce subject teacher)

Thinking skills and problem solving applications were observed in the T\&L activities conducted by the research participants as the questions were mostly driven on current issues that were slightly controversial. The opportunities and encouragement given to students to criticize and argue; and a little authority for the students to determine the course of T\&L activities were able to encourage students to develop strategies to ensure the success of these activities. 


\section{Discussion and Conclusions}

The findings showed that teachers used their professional local knowledge by taking into account their professional abilities and students' ability to produce approaches, methods and techniques that are suitable as pedagogical actions which can promote thinking skills. Through questioning techniques, teachers encouraged students in expressing their views and opinions through questions posed to students. Teachers understand their students' abilities and ask appropriate questions to stimulate students' thinking activities. Teacher-student interaction usually happens from an open-ended question or a closed question in accordance with the level of students' abilities, the subject matter and objectives of the executed T\&L. Tofade, Elsner and Haines (2013) and Critelli and Tritapoe (2010) stated that open-ended questions can encourage students to reason and use their existing knowledge and they should regularly be given to students. Questions filed by the teacher is then followed by probing, the follow-up questions to encourage students to continue conducting thinking activities. As stated by Critelli and Tritapoe (2010) this is as an effective technique to develop the mind of students and promote sustainable responses from them.

This study also showed that the encouragement and opportunities offered by the teacher to the students to ask questions between them are also seen to be very effective in promoting thinking skills among students. According to the teachers surveyed, by allowing students to generate their own questions can lead to a better understanding than having the teachers to continuously provide questions to the students. Tofade et al. (2013) stated that questions coming from students also allow profound learning. Students' freedom to voice out not only gives them space to question but also allows them to criticize and defend their arguments. Professional knowledge of teachers in providing encouragement so that the students dare to express their opinion has been able to improve students' ability to argue and criticize. The ability to criticize and argue contributes to the students becoming open to the ideas of others, ready to listen and work together to solve the problems (Rajendran, 2002).

The teachers also encouraged students involvement in giving opinions by highlighting current issues and controversies through approaches and techniques appropriate to the abilities of their students. This was also proposed by Deuchar (2009) and MacMath (2008), which affirmed the discussion of current issues related to the process of the T\&L in the classroom will provide students with profound knowledge of the issues, educate them to respect the views of others, become more skilled in presenting the arguments which results in increased involvement of students in T\&L activities. The active involvement of students and the exchange of views between them can be observed when the current or controversial issues were discussed such as polygamy (Ms. Emi), the dignity of young women (Ms. Azim) and the symbol of the country (Ms. Hani). Discussions of these issues were deliberately designed by the teachers through their practical experience and knowledge. By involving students in a discussion of current issues, students will understand a topic better as asserted by Ms. Hani, “... So, if we do not stimulate, we don't illustrate based on visible events, when they read the question, they don't actually know how to relate to it. This means that we can't just teach based on textbooks alone, we have to relate them with the current issues" (Ms. Hani/History Teacher).

Teachers who share authority with students have managed to educate students to become more responsible towards their learning, and students were more involved in their given tasks (McCombs, undated). By giving autonomy to the students in their learning activities increases their motivation and involvement. William and William (2011) stated that a person will be more motivated to do something on their own choice rather than told to do something that is not their choice. This confirms the results obtained in the observations of Ms. Azim classes when students were able to provide arguments to support their debate topics which were submitted on their own. As a result, students can display their true abilities beyond the teachers "expectations. Ms. Azim who is aware of her students" limited ability to converse in English still gave them opportunities to propose the topics to be debated. Despite the fact that the topic suggested by the students did not meet the correct sentence structure, Ms. Azim still accepted the proposal and even praised the ability of those who managed to suggest the topic of the debate. Autonomous learning provided to the students had given motivation for students to participate more actively in the T\&L process. For example in Ms. Azim's classes, she understands the ability of her students to understand English and accepts their suggestions first (does not immediately correct their sentences) and then asks all of her students to correct the sentences together. These observations highlighted the professional local knowledge of the teachers to adjust their teaching methods to adapt with students' ability, which not only motivates students to participate in the T\&L process but also to hone their soft skills. Ms. Azim had combined her knowledge on the ability of her students in the school, "... even if the school is a former English medium school in which English is supposed to serve as the primary language of the student, but it isn't. Students are still ashamed, afraid to speak in English..." and "... they're students, they actually prefer to do fun things..." (Ms. Azim/English Tecaher). 
This study showed that teachers as professionals are knowledgeable about their environment, their students and able to provide a positive impact on their students learning. However, teachers must constantly refine their professional local knowledge through continuous reflection or conduct a systematic inquiry on teaching approaches. Teachers should be more open to criticism, especially from other fellow teachers as suggested by Walker et al. (2009) to avoid the reflective practice to end up as a usual class routine and not providing any impact on the teacher's professional local knowledge. Professional local knowledge of teachers in their pedagogical practice was guided by experience and their understanding of the surrounding and the students they faced, which described by Gholami (2009) as moral and intellectual dignity rooted in a human soul to do the right thing in the right place at the right time in the right way.

\section{Acknowledgements}

This research funded by USM Research University Grant 1001/PGURU/816258.

\section{References}

Burnard, P., Gill, P., Stewart, K., Treasure, E., \& Chadwick, B. (2008). Analysing and Presenting Qualitative Data. British Dental Journal, 204(8). https://dx.doi.org/10.1038/sj.bdj.2008.292

Canagarajah, S. (2002). Reconstructing Local Knowledge. Journal of Language, Identity, and Education, 1(4), 243-259. https://dx.doi.org/10.1207/S15327701JLIE0104_1

Chen, C. (2005). Teachers as Change Agents: A Study of In-Service Teachers' Practical Knowledge. Action in Teacher Education, 26(4), 10-19. https://dx.doi.org/10.1080/01626620.2005.10463339

Cloke, C., Sharif, S., \& Ambotang, A. S. (2006). A Qualitative Study of Pedagogical Issues Arising from the Introduction of the Malaysian Smart School Initiative. Jurnal Pendidik dan Pendidikan, 21, 129-147.

Cochran-Smith, M., \& Lytle, S. L. (1999). Relationships of Knowledge and Practice: Teacher Learning in Communities. Review of Research in Education, 24, 249-305. https://dx.doi.org/10.2307/1167272

Connelly, F. M., Clandinin, D. J., \& He, M. F. (1997). Teachers' personal practical knowledge on the professional knowledge landscape. Teaching and Teacher Education, 13(7), 665-674. https://dx.doi.org/10.1016/S0742-051X(97)00014-0

Creswell, J. W. (2012). Educational Research: Planning, Conducting and Evaluating Quantitative and Qualitative Research Fourth Edition. Boston: Pearson.

Critelli, A., \& Tritapoe, B. (2010). Effective Questioning Techniques to Increase Class Participation. e-Journal of Student Research, 2(1).

Darling-Hammond, L. (2000). Teacher Quality and Students'Achievement. https://dx.doi.org/10.14507/epaa.v8n1.2000

Deuchar, R. (2009). Seen and Heard, and Then Not Heard: Scottish Pupils' Experience of Democratic Educational Practice during the Transition from Primary to Secondary School. Oxford Review of Education, 35(1), 23-40. https://dx.doi.org/10.1080/03054980802018871

Fenstermacher, G. D. (1994). The knower and the known: The nature of knowledge in research on teaching. In L. Darling-Hammond (Ed.), Review of Research in Education (Vol. 20, pp. 1-54). Washington, DC: American Educational Research Association. https://dx.doi.org/10.2307/1167381

Fredriksen, K., \& dan Rhodes, J. (2004). The Role of Teacher Relationships in the Lives of Students. New Directions for Student Leadership, 2004(103), 45-54. https://dx.doi.org/10.1002/yd.90

Gholami, K. (2009). Representing the epistemic nature of teachers' practical knowledge: The case of class teachers' general pedagogy. University of Helsinki.

Golafshani, N. (2003). Understanding Reliability and Validity in Qualitative Research. The Qualitative Report, $8(4), 597-606$.

Goldenberg, C., \& Gallimore, R. (1991). Local Knowledge, Research Knowledge and Educational Change: A Case Study of Early Spanish Reading Improvement. Educational Researcher, 20(2), 1-13. https://dx.doi.org/10.3102/0013189x020008002

Grossman, P. L. (1990). The Making of a Teacher: Teacher Knowledge and Teacher Education. New York: Teacher's College Press. 
Guzman, C. (2009). Developing Craft Knowledge in Teaching at University: How do beginning teachers learn to teach? European Educational Research Journal, 8(2), 326-335. https://dx.doi.org/10.2304/eerj.2009.8.2.326

Hall, D. (2011). Debate innovative teaching to enhance critical thinking and communication skills in healthcare professionals. The Internet Journal of Allied Health Sciences and Practice. Retrieved May 9, 2013, from http://ijahsp.nova.edu/articles/Vol9Num3/pdf/Hall.pdf

Halpern, D. F. (1996). Thought and knowledges: An introduction to critical thinking (3rd ed.). Mahwah, N.J: Lawrence Arlbaurn Associates.

Hardman, J. (2008). Researching pedagogy: An activity theory approach. Journal of Education, 45, 65-95.

Hashim, R., \& Hussein, S. (2003). The Teaching of Thinking in Malaysia. Kuala Lumpur: Research Centre IIUM.

Hattie, J. (2003). Teachers Make a Difference What Is the Research Evidence? Retrieved January 15, 2009, from http://www.docstoc.com/docs/2251792/Teachers-Makea-Difference

How, L. C. (2007). Faktor-faktor yang Mempengaruhi Gejala Ponteng di kalangan Pelajar Sekolah Menengah. In Kertas Tesis Sarjana (Tidak Diterbitkan). Skudai: Universiti Teknologi Malaysia.

Johnson, K. E. (2006). The Sociocultural Turn and Its Challenges for Second Language Teacher Education. Tesol Quarterly, 40(1), 235-257. https://dx.doi.org/10.2307/40264518

Kementerian Pendidikan Malaysia. (2013). Pelan Pembangunan Pendidikan Malaysia 2013-2025. Putrajaya: Kementerian Pendidikan Malaysia.

Lincoln, Y. S., \& Guba, E. G. (1985). Naturalistic Inquiry. Newbury Park, Ca: Sage Publications Inc.

Liu, S. (2010). Teachers' Knowledge: Review from Comparative Perspective. New Horizons in Education, 58(1), 148-158.

MacIntyre, A. (1982). After virtue: A case study in moral theory. London: Duckworth.

MacMath, S. (2008). Implementing a Democratic Pedagogy in the Classroom: Putting Dewey into Practice. Canadian Journal for New Scholars in Education, 1(1), 1-12.

Marshall, C., \& B. Rossman, G. (2006). Designing Qualitative Research. California: Sage Publication Inc.

McCombs, B. L. (n.d.). Developing Responsible and Autonomous Learners: A Key to Motivating Students-Teacher's Modules. Retrieved September 7, 2014, from $\mathrm{http} / / / \mathrm{www}$.apa.org/education/k12/learners.aspx?item=1

Miles, M. B., \& Huberman, A. M. (1994). Qualitative Data Analysis an Expanded Sourcebook (2nd ed.). California: Sage Publications.

Ministry of Education. (2012). Preliminary Report Malaysia Education Blueprint 2013-2025. Putrajaya.

MohamadSaid, M. M., \& Yunos, N. (2008). Peranan guru dalam memupuk kreativiti pelajar. MALIM: Jurnal Pengajian Umum Asia Tenggara, 9, 57-71.

Morse, J. M., Barrett, M., Mayan, M., Olson, K., \& Spiers, J. (2002). Verification Strategies for Establishing Reliability and Validity in Qualitative Research. International Journal of Qualitative Methods, 1(2), 1-19.

Munzenmaier, C. (2013). Bloom's taxonomy: What's old is new again. The Learning Guild Research. Retrieved February 6, 2015, from http://www.lessonpaths.com/learn/i/information-literacy-issues/blooms-taxonomy-whats-old-is-new-again2

Neergaard, H., \& Olhoi, J. P. (2006). Handbook of Qualitative Research Methods in Entreprenuership. Edward Elgar Publishing Limited, Cheltenham.

Onosko, J. J., \& Newmann, F. M. (1994). Creating More Thoughtful Learning Environment. In J. Mangieri, \& C. C. Blocks (Eds.), Creating Powerful Thinking in Teachers and Students: Diverse Perspectives. Forth Worth: Harcourt Brace College Publishers.

Patton, M. Q. (2002). Qualitative Research and Evaluation Methods (3rd ed.). California: Sage Publications.

Pusat, P. K. (2002). Kemahiran Berfikir dalam Pengajaran dan Pembelajaran. Kementerian Pendidikan Malaysia.

Rajendran, N. (2001). Pengajaran Kemahiran Berfikir Asas Tinggi: Kesediaan Guru Mengendalikan Proses Pengajaran Pembelajaran. Paper presented at the Warisan-Pendidikan-Wawasan. 
Rajendran, N. (2002). Using Constructivist Approach to Teach Higher-Order Thinking Skills: Transforming Teaching Practice to Facilitate Mindful Learning. Paper presented at the 10th International Conference on Thinking, Harrogate, England.

Richardson, V. (1994). Conducting Research on Practice. Educational Researcher, 23(5), 5-10. https://dx.doi.org/10.3102/0013189X023005005

Rowe, K. J. (2000). Exploring Real Effects from Evidence-based Research in Teacher and School Effectiveness. The Educational Performance of Males and Females in School and Tertiary Education. Paper presented at Educational Attainment and Labour Market Outcomes: Factors Affecting Boys and Their Status in Relation to Girls, Melbourne, Australia.

Rowe, K. J. (2002). The Importance of Teacher Quality.

Salleh, A. R. (2003). Pemikiran Profesional Keguruan Terhadap Kurikulum dan Pengajaran. Dibentangkan di Seminar Pendidikan MPBL.

Sanders, W. L., \& dan Rivers, J. C. (1996). Cumulative and Residual Effects of Teachers of Future Students Academic Achievement.

Schon, D. (1987). The Crisis of Professional Knowledge and the Pursuit of an Epistemology of Practice. In C. Bames, R. Christensen, \& A. Hansen (Eds.), Teaching and the Case Method, Instruction Guide (pp. 241-254).

Shenton, A. K. (2004). Strategies for Ensuring Trustworthiness in Qualitative Research Projects. Education for Information, 22, 63-75.

Shulman, L. S. (1987). Knowledge and Teaching: Foundations of the New Reform. Harvard Educational Review, 57(1), 1-22. https://dx.doi.org/10.17763/haer.57.1.j463w79r56455411

Slavin, R. E. (1996). Research on Cooperative Learning Achievement: What we Know, What we Need to Know. Contemporary Educational Psychology, 21, 43-69. https://dx.doi.org/10.1006/ceps.1996.0004

Tofade, T., Elsner, J., \& Haines, S. T. (2013). Best Practice Strategies for Effective Use of Questions as a Teaching Tool. American Journal of Pharmaceutical Education, 77(7), 1-9. https://dx.doi.org/10.5688/ajpe777155

Verloop, N., Driel, J. V., \& Meijer, P. (2001). Teacher Knowledge and the Knowledge Base of Teaching. International Journal of Educational Research, 35, 441-461. https://dx.doi.org/10.1016/S0883-0355(02)00003-4

Walker, N. T., Wimmer, J., \& Bean, T. (2009). Multiple Texts, Teacher Craft Knowledge, and Principled Practices in High School Economics: A Case Study of Kenneth. Social Studies Research and Practice, 4(3), 28-35.

Williams, K. C., \& Williams, C. C. (2011). Five key ingredients for improving student motivation. Research in Higher Education Journal, 12.

Yang, C. H., \& Rusli, E. (2012). Using debate as a pedagogical tool in enhancing pre-service teachers' learning and critical thinking. Journal of International Education Research, 8(2). https://dx.doi.org/10.19030/jier.v8i2.6833

Yin, R. K. (2009). Case Study Research Design and Methods (4th ed.). California: Sage Publication Inc.

\section{Copyrights}

Copyright for this article is retained by the author(s), with first publication rights granted to the journal.

This is an open-access article distributed under the terms and conditions of the Creative Commons Attribution license (http://creativecommons.org/licenses/by/4.0/). 